\title{
Large intraocular foreign body following a firecracker injury
}

\author{
Amar Pujari, Mandeep Bajaj, Devashish Dubey
}

Dr Rajendra Prasad Centre for Ophthalmic Sciences, All India Institute of Medical Sciences, New Delhi, New Delhi, India

\section{Correspondence to} Dr Amar Pujari, dramarpujari@gmail.com

Accepted 1 December 2016

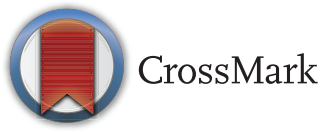

To cite: Pujari A, Bajaj M, Dubey D. BMJ Case Rep Published online: [please include Day Month Year] doi:10.1136/bcr-2016218565

\section{DESCRIPTION}

An 8-year-old girl child presented with the history of firecracker injury to the right eye. There was a sudden loss of vision associated with pain, redness and watering. Primarily, she was diagnosed as panophthalmitis and started of intravenous antibiotics, but as the condition worsened she was referred to a tertiary eye hospital. Initial examination was painful tense upper and lower eyelid oedema (figure 1A) along with severely chemosed conjunctiva and with severely restricted extraocular motility in all the gazes; the child denied any perception of light in the right eye, whereas left eye was normal. Ultrasonography showed a large highamplitude opacity filling almost two-third of the vitreous cavity with shadowing posterior. (figure 1B). Subsequent CT of the orbit showed large hyperdense foreign body almost filling the entire vitreous cavity. (figure 1C). The patient was started on intravenous antibiotics injection vancomycin $40 \mathrm{mg} / \mathrm{kg}$ in two divided doses, injection piperacillin and tazobactam $4.5 \mathrm{~g}$ in three decided doses. The patient was fit for general anaesthesia on day 2, as the ocular condition was worsening; the foreign
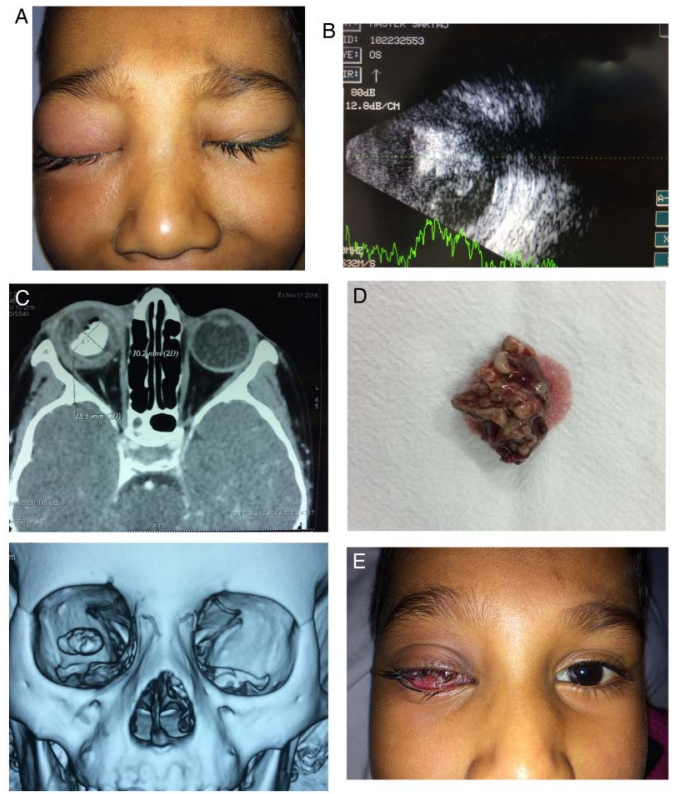

Figure 1 (A) Tense painful eyelid swelling. (C) Non-contrast CT of the orbit showing large intraocular hyperdense foreign body with three-dimensional image reconstructions. (B) Ultrasonography revealed large high-amplitude spike mass filling the major portion of the vitreous cavity with shadowing. (D) Foreign after removal showed a mixture of stone particles, necrotic wood and purulent material. (E) Postoperatively after 5 days of foreign body removal with improved clinical condition. body was removed along with evisceration with Mule's implant placement on day 2 under general anaesthesia. The nature of the foreign body was a mixture of stone particles, necrotic wood and purulent material (Figure 1D). Intravenous antibiotics were continued for 5 more days until the resolution of periorbital swelling (figure 1E) after that oral antibiotic was continued for one more week.

Intraocular foreign bodies are a challenge in diagnosis and treatment. It is an important ophthalmological emergency. These are usually due to mishaps at the workplace (metalworking), road traffic accidents and gunshot injuries, but firecracker injury is an important concern in our country. Ophthalmic evaluation includes visual acuity assessment, anterior chamber, posterior chamber and fundus examination. $\mathrm{X}$-ray is useful in visualisation of the radiopaque foreign bodies, but ultrasonography is also an important modality in the assessment of other ocular structures such as posterior capsular status, vitreous and retinal status. Other imaging modalities include CT scan for radiopaque foreign body and MRI, for nonmetallic foreign bodies but CT is useful in precisely localising the foreign body within the globe, then the orbit followed by bony relation and intracranial status. Organic foreign bodies should be removed to prevent further complications. ${ }^{1-3}$

In this case, the foreign body was removed along with the all necrotic intraocular contents (evisceration).

\section{Learning points}

- The treatment of choice for an organic foreign body is early removal to minimise the damage along with an effort to preserve the normal tissue as much as possible.

- A multidisciplinary approach with aggressive medical and surgical management will help in achieving maximal visual and cosmetic results.

Contributors All authors have approved the final manuscript for publication.

Competing interests None declared.

Patient consent Obtained.

Provenance and peer review Not commissioned; externally pee reviewed.

\section{REFERENCES}

1 Imrie FR, Cox A, Foot B, et al. Surveillance of intraocular foreign bodies in the UK. Eye (Lond) 2008:22:1141-7.

2 Parke DW, Flynn HW, Fisher YL. Management of intraocular foreign bodies: a clinical flight plan. Can J Ophthalmol 2013:48:8-12.

3 Gaković A, Kovačević I, Biševac J, et al. Big intraocular foreign body: case report. Srp Arh Celok Lek 2013;141:516-18. 
Copyright 2016 BMJ Publishing Group. All rights reserved. For permission to reuse any of this content visit http://group.bmj.com/group/rights-licensing/permissions.

BMJ Case Report Fellows may re-use this article for personal use and teaching without any further permission.

Become a Fellow of BMJ Case Reports today and you can:

- Submit as many cases as you like

- Enjoy fast sympathetic peer review and rapid publication of accepted articles

- Access all the published articles

- Re-use any of the published material for personal use and teaching without further permission

For information on Institutional Fellowships contact consortiasales@bmjgroup.com

Visit casereports.bmj.com for more articles like this and to become a Fellow 